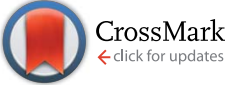

Cite this: RSC Adv., 2017, 7, 2573

\title{
A novel ratiometric fluorescent probe for selective detection of bisulfite in living cells $\uparrow$
}

\author{
Zhen Chen, Fengzao Chen, Yuanchao Sun, Heng Liu, ${ }^{*}$ Hanping He, Xiuhua Zhang \\ and Shengfu Wang
}

A new type of ratiometric fluorescent probe, 8-(diethylamino)-2-methyl-4-oxo-4H-pyrano[2,3-b] chromen-10-ylium tetrafluoroborate (APCT), is reported. A new type of ratiometric fluorescent probe, 8(diethylamino)-2-methyl-4-oxo-4H-pyrano[2,3-b]chromen-10-ylium tetrafluoroborate (APCT), is reported. This probe can successfully detect bisulfite anions with a detection limit of $6.1 \times 10^{-7} \mathrm{M}$ based on Michael-type addition reaction in $\mathrm{pH}=7.4$ Tris buffer solution containing $70 \% \mathrm{DMSO}(\mathrm{v} / \mathrm{v})$. The response time of the probe is approximately $5 \mathrm{~min}$. Upon treating with bisulfite anions, the probe exhibits an obvious blue shift from $560 \mathrm{~nm}$ to $510 \mathrm{~nm}$ and the fluorescence intensity ratio at $510 \mathrm{~nm}$ and $560 \mathrm{~nm}\left(/_{510} / /_{560}\right)$ displays a good linear relationship with the concentration of $\mathrm{HSO}_{3}{ }^{-}$in the range of 20-120 $\mu \mathrm{M}$. Additionally, the preliminary cell imaging experiments using HeLa cells demonstrate that the probe can be used to detect intracellular bisulfite anions.

Received 25th November 2016 Accepted 21st December 2016

DOI: $10.1039 /$ c6ra27347e

www.rsc.org/advances

Compared with traditional detection method, fluorescent

\section{Introduction}

As one kind of main environmental air pollutant, sulfur dioxide $\left(\mathrm{SO}_{2}\right)$ is mainly derived from human activities such as burning of fossil fuel, paper pulp manufacturing and metal processing, causing mortal threats to human health. ${ }^{1} \mathrm{SO}_{2}$ inhaled by human beings will be hydrated to the corresponding bisulfite $\left(\mathrm{HSO}_{3}{ }^{-}\right)$and sulfite $\left(\mathrm{SO}_{3}{ }^{2-}\right)$ derivatives in the neutral physiological environment. ${ }^{2}$ In daily life, bisulfite and sulfite $\left(\mathrm{HSO}_{3}{ }^{-} /\right.$ $\mathrm{SO}_{3}{ }^{2-}$ ) play an important role in food, beverages, and pharmaceutical products, because they can prevent oxidation, and microbial reactions during production and storage. ${ }^{3}$ Epidemiological studies have indicated that frequent exposure to $\mathrm{SO}_{2}$, not only gives rise to a variety of respiratory tract reaction, ${ }^{4}$ but also is related to cardiovascular diseases, ${ }^{5}$ lung cancer and many kinds of neurological disorders. ${ }^{6}$ However, as an important gaseous signal molecule, endogenous $\mathrm{SO}_{2}$, which can be produced by sulfur-containing amino acid, can together with nitric oxide (NO) as vasodilator substance to regulate the vascular smooth muscle. ${ }^{7}$ Taking into account the close relationship between $\mathrm{SO}_{2}$ derivatives and human health, there is urgently needed to develop simple, high selectivity and selectivity method for detecting of $\mathrm{HSO}_{3}{ }^{-} / \mathrm{SO}_{3}{ }^{2-}$ ion and make further efforts to elucidate their detailed biological and pharmacological functions.

Hubei Collaborative Innovation Center for Advanced Organic Chemical Materials, Ministry of Education Key Laboratory for the Synthesis and Application of Organic Functional Molecules \& College of Chemistry and Chemical Engineering, Hubei University, Wuhan 430062, PR China. E-mail: liuheng11b@hubu.edu.cn

$\dagger$ Electronic supplementary information (ESI) available. See DOI: 10.1039/c6ra27347e probes and imaging techniques have a number of significant advantages including simple sample pretreatment, rapid response time, high sensitivity and suitable for highthroughput screening application. ${ }^{\mathbf{8}}$ Therefore, in recent years, fluorescent probes are increasingly considered as one of efficient tools for monitoring cations, anions and biomolecules. ${ }^{9}$ To date, a large quantity of fluorescent probes capable of selective response to $\mathrm{SO}_{2}$ and its derivatives have been reported based on three disparate approaches, including aldehydes ${ }^{\mathbf{1 0}}$ or Michael-type addition reaction, ${ }^{\mathbf{1 1}}$ levulinate esters cleavage reaction ${ }^{12}$ and coordinative interactions. ${ }^{13}$ However, some of the reported $\mathrm{SO}_{2}$-specific fluorescent probes suffer from low selectivity over reactive sulfur especially for biothiols and slow response time, which greatly limits their biological applications. Additionally, some $\mathrm{SO}_{2}$-specific fluorescent probes are developed on the basis of fluorescence enhancement or quenching of a single fluorophore and have many limitations such as probe concentration, environmental effects, excitation power and detector sensitivity. ${ }^{\mathbf{1 4}}$ In order to get over the limitations, ratiometric fluorescent probes are desirable because they can effectively eliminate external interferences by selfcalibration two emission bands. ${ }^{15}$ As a consequence, developing novel ratiometric fluorescent probes for detection of $\mathrm{HSO}_{3}{ }^{-} / \mathrm{SO}_{3}{ }^{2-}$ is of great importance.

In this paper, we described the synthesis of a novel ratiometric fluorescent probe (APCT) for $\mathrm{HSO}_{3}{ }^{-} / \mathrm{SO}_{3}{ }^{2-}$ based on Michael-type addition reaction. The probe displayed high selectivity for detection of $\mathrm{HSO}_{3}{ }^{-} / \mathrm{SO}_{3}{ }^{2-}$ over other interfering species with detection limit down to $6.1 \times 10^{-7} \mathrm{M}$. Meanwhile, upon treatment with $\mathrm{HSO}_{3}{ }^{-}$, the fluorescence emission peak of 
the probe exhibited an obvious blue shift from $560 \mathrm{~nm}$ to $510 \mathrm{~nm}$. The sensing mechanism research showed that the conjugate structure of probe-APCT was destroyed. Preliminary cell experiments also confirmed that probe-APCT could be used for intracellular $\mathrm{HSO}_{3}{ }^{-}$detection.

\section{Experimental}

\section{Chemicals and apparatus}

All reagents and solvents were purchased from commercial suppliers and used without further purification. Distilled water was used in the experiment after passing through a water ultrapurification system. Reactions were monitored by TLC. Column chromatographic were carried out using 200-300 mesh silica with the proper solvent according to TLC using UV light to visualize the reaction components. The fluorescence spectra and relative fluorescence intensity were measured by a Shimadzu RF-5301 spectrofluorimeter, the excitation wavelength was $465 \mathrm{~nm}$ for all fluorescence measurements, the excitation slit width and the emission slit width set at $3 \mathrm{~nm}$. UV-Vis absorption spectra were measured using a Shimadzu UV-2700 spectrophotometer. ${ }^{1} \mathrm{H}$ NMR and ${ }^{13} \mathrm{C}$ NMR spectra were recorded on a BRUKER 400 spectrometer. The $\mathrm{pH}$ was measured with a PHS-3C acidometer. Electrospray mass spectra (ESI-MS) were recorded on Agilent 1100 Series. Cells images were obtained using CLSM TCS SP5 (Leica, Germany).

\section{Synthesis of APCT}

In a $50 \mathrm{~mL}$ round-bottom flask, 4-hydroxy-6-methyl-2H-pyran-2one $(1.26 \mathrm{~g}, \quad 10 \mathrm{mmol})$ and 4-(diethylamino)-2hydroxybenzaldehyde $(2.32 \mathrm{~g}, 12 \mathrm{mmol})$ were dissolved in ethanol $(20 \mathrm{~mL})$ and the resulting mixture was stirred at $80{ }^{\circ} \mathrm{C}$ for $4 \mathrm{~h}$. After cooling to room temperature, the red solid was collected by suction filtration and then recrystallized from ethanol to afford the desired product $\mathrm{C} 1$ as red powder $(2.45 \mathrm{~g}$, yield $70 \%$ ).

Compound C1 (602 mg, $2 \mathrm{mmol}$ ) and boron trifluoride ethyl etherate $(283.5 \mathrm{mg}, 2 \mathrm{mmol})$ were mixed in component solvent (acetic acid/acetic anhydride $=3: 1,9 \mathrm{~mL} / 3 \mathrm{~mL}, \mathrm{v} / \mathrm{v}$ ), and the resulting solution was refluxed until completion of the reaction (monitored by TLC). The red solid precipitated upon cooling was collected by suction filtration and then washed with methyl tert-butyl ether to afford the target fluorescent probe-APCT (515 mg, yield 60\%). ${ }^{1} \mathrm{H}$ NMR (400 MHz, d $\mathrm{d}_{6}$-DMSO): $\delta 8.87$ (s, $1 \mathrm{H}), 7.83(\mathrm{~d}, J=9.3 \mathrm{~Hz}, 1 \mathrm{H}), 7.34(\mathrm{~s}, 1 \mathrm{H}), 6.92(\mathrm{dd}, J=9.2$, $2.4 \mathrm{~Hz}, 1 \mathrm{H}), 6.67(\mathrm{~d}, J=2.2 \mathrm{~Hz}, 1 \mathrm{H}), 3.57$ (q, $J=7.1 \mathrm{~Hz}, 4 \mathrm{H}), 2.37$ (s, 3H), 1.17 (t, $J=7.1 \mathrm{~Hz}, 6 \mathrm{H}) ;{ }^{13} \mathrm{C}$ NMR (100 MHz, d $\mathrm{d}_{6}$-DMSO): $\delta$ 190.3, 176.3, 158.8, 158.5, 155.1, 149.2, 133.9, 111.5, 109.2, 105.8, 98.9, 96.1, 44.9, 24.3, 12.4; LC-MS TOF: calcd for $\mathrm{C}_{17} \mathrm{H}_{18} \mathrm{BF}_{4} \mathrm{NO}_{3}[\mathrm{M}+\mathrm{H}]^{+}$: 371.1; found: 372.1 .

\section{General procedure for the spectra measurement}

The stock solution of probe $(5.0 \mathrm{mM})$ was prepared in DMSO. Solutions of various testing species $\left(\mathrm{ClO}^{-}, \mathrm{HCO}_{3}{ }^{-}, \mathrm{CH}_{3} \mathrm{COO}^{-}\right.$, $\mathrm{PO}_{4}{ }^{3-}, \mathrm{CO}_{3}{ }^{2-}, \mathrm{SO}_{4}{ }^{2-}, \mathrm{HSO}_{4}{ }^{-}, \mathrm{H}_{2} \mathrm{PO}_{4}{ }^{-}, \mathrm{NO}_{2}{ }^{-}, \mathrm{F}^{-}, \mathrm{Cl}^{-}, \mathrm{Br}^{-}, \mathrm{I}^{-}$, $\mathrm{HPO}_{4}{ }^{2-}, \mathrm{SCN}^{-}, \mathrm{S}^{2-}, \mathrm{H}_{2} \mathrm{O}_{2}, \mathrm{GSH}, \mathrm{Cys}, \mathrm{Hcy}, \mathrm{SO}_{3}{ }^{2-}, \mathrm{HSO}_{3}{ }^{-}$) were prepared in twice distilled water. All of anions were prepared from their sodium salts. The resulting solution was kept at room temperature $\left(25^{\circ} \mathrm{C}\right)$ and then the absorption or fluorescence spectra were recorded.

\section{Cell culture and imaging}

HeLa cells were cultured in Dulbecco's Modified Eagle Medium (DMEM) supplemented with 10\% (v/v) fetal bovine serum (FBS), 100 units per $\mathrm{mL}$ of penicillin and 100 units per $\mathrm{mL}$ of streptomycin at $37{ }^{\circ} \mathrm{C}$ in a $\mathrm{CO}_{2}$ incubator, and culture media were replaced with fresh media every day. The HeLa cells were pretreated with $100 \mu \mathrm{M} \mathrm{HSO}_{3}{ }^{-}$, and then further incubated with 10 $\mu \mathrm{M}$ of probe-APCT for $30 \mathrm{~min}$ at $37{ }^{\circ} \mathrm{C}$. In the control experiment, HeLa cells were incubated with $10 \mu \mathrm{M}$ of probe-APCT for $30 \mathrm{~min}$ at $37^{\circ} \mathrm{C}$. The cells were washed three times with PBS buffer before cell fluorescence imaging experiments with confocal laser scanning microscopy.

\section{Results and discussion}

The synthesis of the target fluorescent probe (APCT) was shown in Scheme 1. According to the designed route, compound C1 was synthesized via the condensation of 4-(diethylamino)-2hydroxybenzaldehyde and 4-hydroxy-6-methyl-2H-pyran-2-one. Followed by the hemiketal, dehydration, aromatization with boron trifluoride diethyl etherate, a new heterocyclic molecule APCT was prepared.

\section{Spectroscopic properties}

For practical applications, a short response time was an important parameter for the target probe. Fig. 1 displayed timedependent fluorescence emission spectra of probe-APCT in the presence of $\mathrm{HSO}_{3}{ }^{-}$. It can be clearly seen that stable fluorescence signal of the probe at $510 \mathrm{~nm}$ and $560 \mathrm{~nm}$ was obtained in approximately $5 \mathrm{~min}$. In view of time-dependent fluorescence emission characteristics of the probe, the following fluorescence measurements were performed about $5 \mathrm{~min}$ after addition of $\mathrm{HSO}_{3}{ }^{-}$.

With the probe in hand, we first carried out the UV-Vis and fluorescence titration experiment in $\mathrm{pH}=7.4$ Tris buffer solution containing 70\% DMSO (v/v). As demonstrated in Fig. 2A, upon increasing of $\mathrm{HSO}_{3}{ }^{-}$amount (6 equiv.), the peak at $510 \mathrm{~nm}$ gradually decreased and the low-energy region of 300-
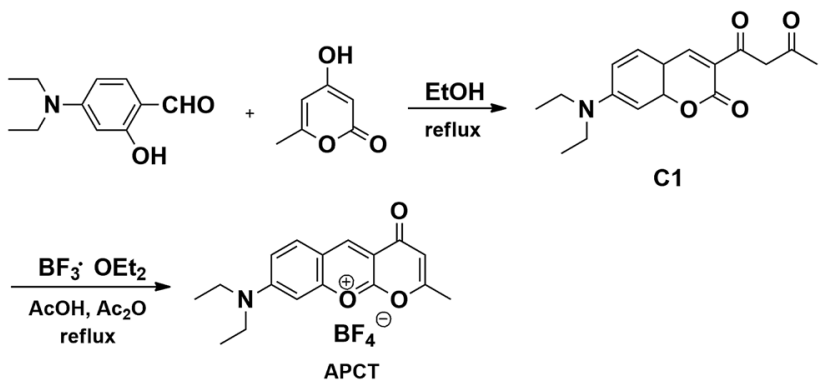

Scheme 1 Synthesis of the target fluorescent probe-APCT. 


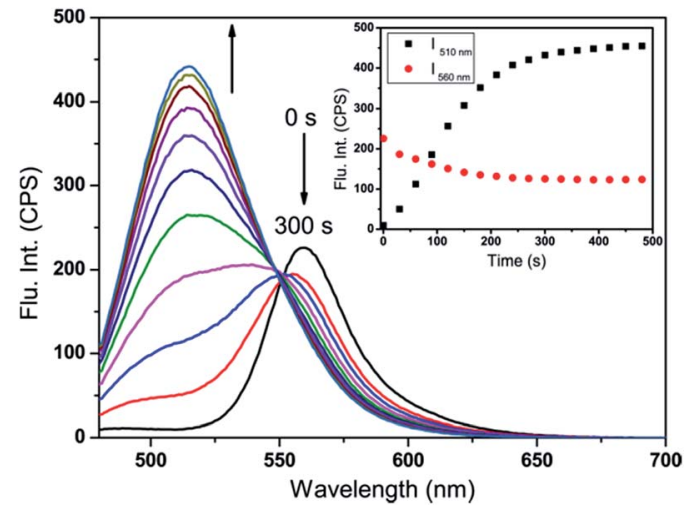

Fig. 1 The time-dependent fluorescence emission spectra $\left(\lambda_{\mathrm{ex}}=465\right.$ $\mathrm{nm}$ ) of probe-APCT upon addition of $120 \mathrm{\mu M} \mathrm{HSO}_{3}{ }^{-}$in $\mathrm{pH}=7.4$ Tris buffer solution containing $70 \%$ DMSO $(\mathrm{v} / \mathrm{v})$ at $25^{\circ} \mathrm{C}$. Slit width: $d_{\mathrm{ex}}=$ $d_{\mathrm{em}}=3 \mathrm{~nm}$.

$375 \mathrm{~nm}$ increased accompanied by the emergence of a welldefined isosbestic point at $445 \mathrm{~nm}$, as well as a noticeable color change from orange-red to yellow. The appearance of new isosbestic point suggested that the interaction of $\mathrm{HSO}_{3}{ }^{-}$and the probe was one-to-one conversion to form a new compound. Subsequently, upon the addition of $\mathrm{HSO}_{3}{ }^{-}$, the marked fluorescence enhancement of the peak at $510 \mathrm{~nm}$ at the expense of the peak at $560 \mathrm{~nm}$ was observed in Fig. 2B. The color of the solution gradually turned from yellow to green under a $365 \mathrm{~nm}$ UV lamp. Fluorescence analysis revealed that the fluorescence quantum yield changed from 0.14 to 0.06 (using FITC as a reference, $\Phi_{\mathrm{FL}}=0.92$ in $0.1 \mathrm{M} \mathrm{NaOH}$ ) before and after the addition of 6 equiv. $\mathrm{HSO}_{3}{ }^{-}$. All the results showed that the asprepared probe could be suitable for colorimetric detection of $\mathrm{HSO}_{3}{ }^{-}$by naked-eyes.

Moreover, we could see from the fluorescence titration experiment that the ratiometric responses $\left(I_{510} / I_{560}\right)$ of probeAPCT kept a balance and unchanged after addition of 6 equiv. $\mathrm{HSO}_{3}{ }^{-}$(Fig. S1 $\dagger$ ). As shown in Fig. 3, a good linear relationship between $I_{510} / I_{560}$ and the concentration of $\mathrm{HSO}_{3}{ }^{-}$in the range of 20-120 $\mu \mathrm{M}\left(R^{2}=0.983\right)$ was displayed. The detection limit $(\mathrm{S} / \mathrm{N}=$ 3) of $6.1 \times 10^{-7} \mathrm{M}$ of the probe was determined according to the fluorescence titration results, which was comparable to most of the reported $\mathrm{SO}_{2}$-specific fluorescent probes (Table $\mathrm{S} 1 \dagger$ ).
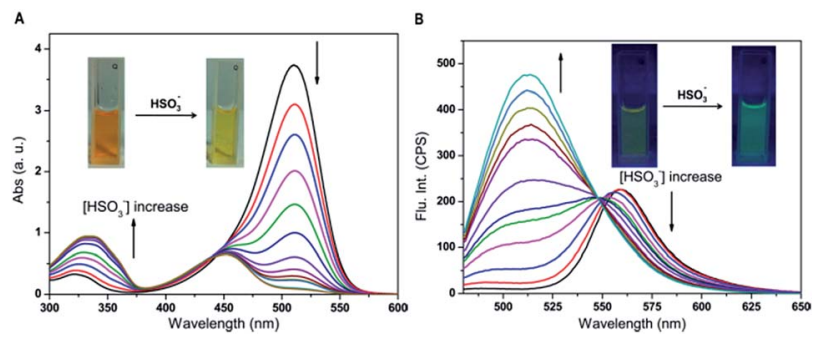

Fig. 2 UV-Vis absorption (A) and fluorescence emission spectra $\left(\lambda_{\text {ex }}=\right.$ $465 \mathrm{~nm})(\mathrm{B})$ of probe-APCT $(20 \mu \mathrm{M})$ upon gradual addition of $\mathrm{HSO}_{3}{ }^{-}$ $(120 \mu \mathrm{M})$ in $\mathrm{pH}=7.4$ Tris buffer solution containing $70 \% \mathrm{DMSO}(\mathrm{v} / \mathrm{v})$ at $25^{\circ} \mathrm{C}$. Slit width: $d_{\mathrm{ex}}=d_{\mathrm{em}}=3 \mathrm{~nm}$.

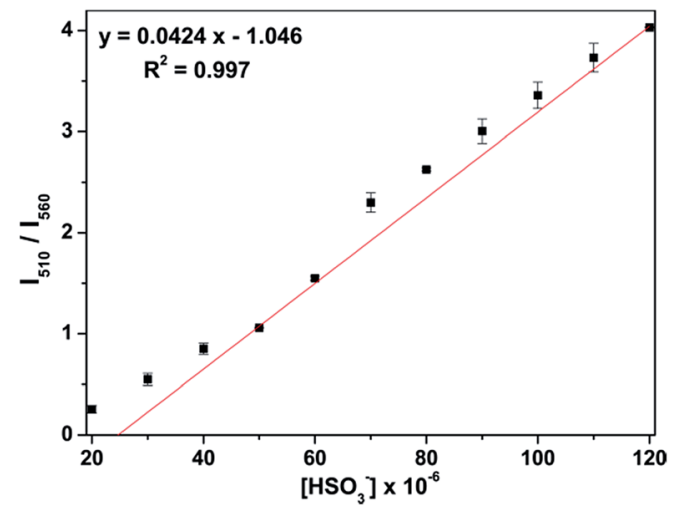

Fig. 3 The ratios of fluorescence intensities $\left(/_{510} / /_{560}\right)$ of probe-APCT $(20 \mu \mathrm{M})$ as a function of the concentration of $\mathrm{HSO}_{3}{ }^{-}$from $20 \mu \mathrm{M}$ to 120 $\mu \mathrm{M}$ in $\mathrm{pH}=7.4$ Tris buffer solution containing $70 \% \mathrm{DMSO}(\mathrm{v} / \mathrm{v})$ at $25^{\circ} \mathrm{C}$. $\lambda_{\mathrm{ex}}=465 \mathrm{~nm}$, slit width: $d_{\mathrm{ex}}=d_{\mathrm{em}}=3 \mathrm{~nm}$.

\section{The selectivity}

In order to evaluate the selectivity of probe-APCT toward $\mathrm{HSO}_{3}{ }^{-}$, a series of common physiologically important species including $\mathrm{ClO}^{-}, \mathrm{HCO}_{3}{ }^{-}, \mathrm{CH}_{3} \mathrm{COO}^{-}, \mathrm{PO}_{4}{ }^{3-}, \mathrm{CO}_{3}{ }^{2-}, \mathrm{SO}_{4}{ }^{2-}, \mathrm{HSO}_{4}{ }^{-}$, $\mathrm{H}_{2} \mathrm{PO}_{4}{ }^{-}, \mathrm{NO}_{2}{ }^{-}, \mathrm{F}^{-}, \mathrm{Cl}^{-}, \mathrm{Br}^{-}, \mathrm{I}^{-}, \mathrm{HPO}_{4}{ }^{2-}, \mathrm{SCN}^{-}, \mathrm{S}^{2-}, \mathrm{H}_{2} \mathrm{O}_{2}, \mathrm{GSH}$, Cys, Hcy, were added to the solution of the probe in $\mathrm{pH}=7.4$ Tris buffer solution containing 70\% DMSO (v/v) (Fig. S2 $\dagger$ ). As illustrated in Fig. $\mathrm{S} 3, \dagger$ upon addition of $\mathrm{HSO}_{3}{ }^{-}$, changes of fluorescence intensity ratio $\left(I_{510} / I_{560}\right)$ reached up to 35 -fold compared to the free probe. In the same test condition, the addition of interfering species only caused a negligible increase in fluorescence intensity ratio $\left(I_{510} / I_{560}\right)$ except a moderate value was detected for $\mathrm{SH}^{-}$. Furthermore, the competitive experiment also carried out in the presence of 6 equiv. $\mathrm{HSO}_{3}{ }^{-}$and 6 equiv. interfering species. It can be clearly seen from Fig. 4 that the ratiometric fluorescence signal response of the probe almost unaffected by interfering species. The above results suggested that the as-prepared probe could highly selective recognize $\mathrm{HSO}_{3}{ }^{-} / \mathrm{SO}_{3}{ }^{2-}$ over other interfering species.

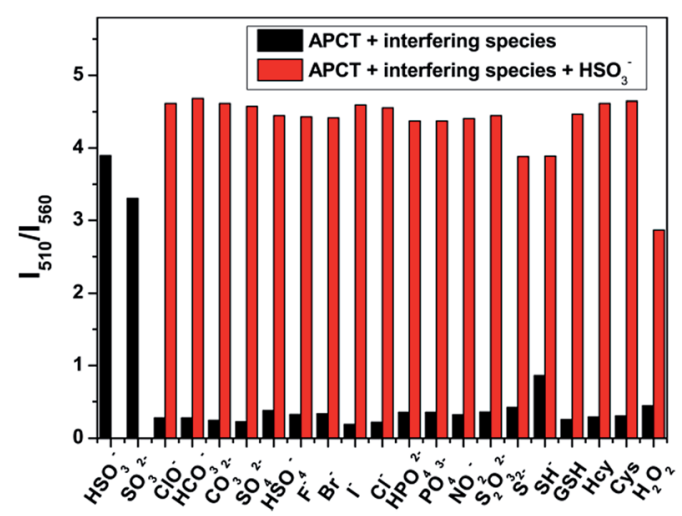

Fig. 4 The selectivity of probe-APCT for $\mathrm{HSO}_{3}{ }^{-}$. Fluorescence intensity ratio $\left(/_{510} / /_{560}\right)$ of probe-APCT $(20 \mu \mathrm{M})$ toward 6 equiv. $\mathrm{HSO}_{3}{ }^{-}$ and 6 equiv. interfering species after incubation in $\mathrm{pH}=7.4$ Tris buffer solution containing $70 \%$ DMSO (v/v) at $25^{\circ} \mathrm{C}$. $\lambda_{\mathrm{ex}}=465 \mathrm{~nm}$, slit width: $d_{\mathrm{ex}}=d_{\mathrm{em}}=3 \mathrm{~nm}$. 


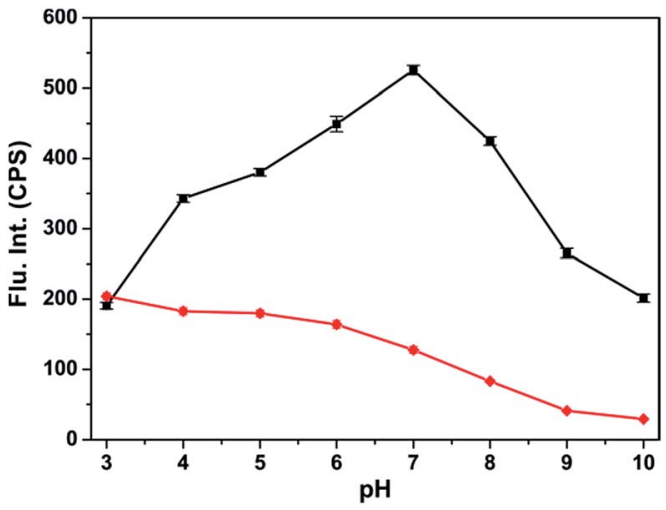

Fig. 5 The fluorescence intensities at $560 \mathrm{~nm}$ and $510 \mathrm{~nm}$ of probeAPCT $(20 \mu \mathrm{M})$ in the presence of 6 equiv. $\mathrm{HSO}_{3}{ }^{-}$at different $\mathrm{pH}$ values.

\section{pH effect}

The effects of $\mathrm{pH}$ on the fluorescence intensities of probe-APCT were investigated at different $\mathrm{pH}$ values. We first evaluated the stability of the probe at $\mathrm{pH}$ from 3.0 to 10.0 . As can be seen from Fig. S4, $\uparrow$ there was virtually no change in the fluorescence intensities at $560 \mathrm{~nm}$ and $510 \mathrm{~nm}$ in the range of $\mathrm{pH}$ 3.0-7.0. The fluorescence intensity at $560 \mathrm{~nm}$ reduced dramatically under alkaline conditions, probably due to the nucleophilic addition of $\mathrm{OH}^{-}$. In the presence of 6 equiv. $\mathrm{HSO}_{3}{ }^{-}$, the fluorescence intensity at $510 \mathrm{~nm}$ appeared remarkable enhancement and achieved maximum at pH 7.4 (Fig. 5). Overall, probeAPCT had the capability to be used for detection of $\mathrm{HSO}_{3}{ }^{-}$in physiological environment.

\section{Sensing mechanism}

To gain further insight into the reaction mechanism of probeAPCT and $\mathrm{HSO}_{3}{ }^{-},{ }^{1} \mathrm{H}$ NMR titration experiment was carried out. As shown in Fig. 6B, upon addition of excessive $\mathrm{HSO}_{3}{ }^{-}$, the NMR signal of $\mathrm{H}_{\mathrm{a}}$ at $8.87 \mathrm{ppm}$ up-field shifted to $4.98 \mathrm{ppm}\left(\mathrm{H}_{\mathrm{a}}^{\prime}\right)$ and other signals of hydrogen were also shifted to high-field with small shift. Such obvious up-field shift of $\mathrm{H}_{\mathrm{a}}$ suggested that a typical nucleophilic addition have been taken place. Another strong evidence of reaction mechanism was from the

A

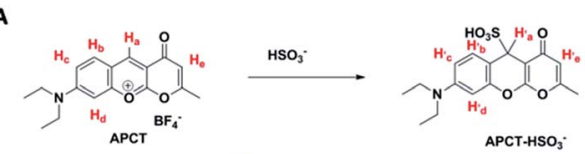

B

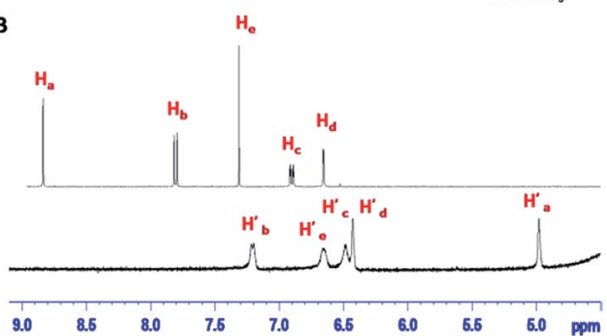

Fig. 6 The mechanism $(A)$ and ${ }^{1} \mathrm{H}$ NMR titration (B) of the reaction between $A P C T$ and $\mathrm{HSO}_{3}{ }^{-}$in $\mathrm{d}_{6}-\mathrm{DMSO}_{2} \mathrm{O}=9 / 1$ (v/v).
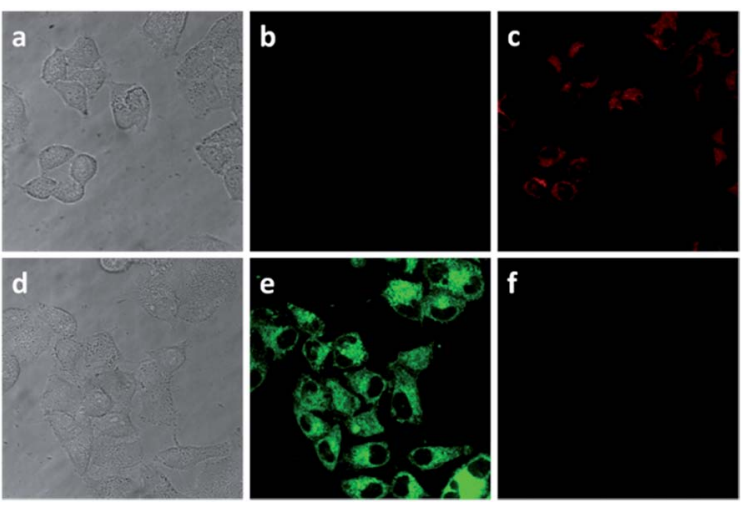

Fig. 7 The top: CLSM fluorescence images $\left(\lambda_{\mathrm{ex}}=405 \mathrm{~nm}\right.$ ) of HeLa cells incubated with probe-APCT for $30 \mathrm{~min}$, (a) bright field; (b) green channel (475-510 nm); (c) red channel (570-625 nm). The bottom: CLSM fluorescence images of HeLa cells pre-treated with $\mathrm{HSO}_{3}{ }^{-}$, and then incubated with probe-APCT for $30 \mathrm{~min}$, (d) bright field; (e) green channel; (f) red channel.

data of LC-MS in Fig. S5. $\uparrow$ Specifically, probe-APCT displayed a main peak at 372.0 before addition of sodium bisulfate, originating from the species $[\mathrm{APCT}+\mathrm{H}]^{+}$. Upon addition of excessive sodium bisulfate, a new peak at 365.1 matched well with the species $\left[\text { APCT }+\mathrm{SO}_{3}{ }^{2-}+\mathrm{H}^{+}\right]^{+}$. Therefore, all these experiment results of ${ }^{1} \mathrm{H}$ NMR and LC-MS indicated that the sensing mechanism of the as-prepared probe-APCT and sodium bisulfate most likely followed the Michael-type addition reaction as shown in Fig. 6A.

\section{Cellular imaging}

Encouraged by the above experiment results, we further investigated the practicability of the probe for intracellular $\mathrm{HSO}_{3}{ }^{-}$. Firstly, the cytotoxicity of the probe was investigated by a standard CCK-8 assay. ${ }^{16}$ The experiment results suggested that the probe exhibited low toxicity on HeLa cells (Fig. S6†). Finally, the applicability of probe-APCT for detection of $\mathrm{HSO}_{3}{ }^{-}$in living cells via confocal laser scanning microscopy (CLSM) was confirmed. The fluorescence images data of HeLa cells incubated with probe-APCT was obtained in the absence and presence of $\mathrm{HSO}_{3}{ }^{-}$(Fig. 7). In a typical imaging experiment, HeLa cells incubated with $10 \mu \mathrm{M}$ free probe emitted moderate red fluorescence and faint green fluorescence with exciting of $405 \mathrm{~nm}$ laser, suggesting that the as-prepared probe have a good cell permeability and suitable for intracellular $\mathrm{HSO}_{3}{ }^{-}$sensing. When HeLa cells was pre-treated with $100 \mu \mathrm{M} \mathrm{HSO}_{3}{ }^{-}$, and then further incubated with $10 \mu \mathrm{M}$ probe-APCT for $30 \mathrm{~min}$, green fluorescence emission markedly enhanced and red fluorescence visibly diminished at the excitation wavelength of $405 \mathrm{~nm}$. The preliminary cell experiment results demonstrated the usefulness of probe-APCT in detecting intracellular $\mathrm{HSO}_{3}{ }^{-}$.

\section{Conclusions}

In conclusion, we have developed a new type of ratiometric fluorescent probe, namely APCT, for $\mathrm{HSO}_{3}{ }^{-}$via the Michael-type 
addition reaction. The probe can discriminate $\mathrm{HSO}_{3}{ }^{-}$from other interfering species with high selectivity and sensitivity. The detection limit of the probe for $\mathrm{HSO}_{3}{ }^{-}$is $6.1 \times 10^{-7} \mathrm{M}$. Additionally, in live cell imaging experiment, the probe give rapid fluorescence changes in red and green channels, revealing the capability of the probe for intracellular $\mathrm{HSO}_{3}{ }^{-}$sensing.

\section{Acknowledgements}

This work was supported by the National Natural Science Foundation of China (NSFC.21602051), the Natural Science Foundation of Hubei Province (2016CFB200) and the Key Project of the Education Department of Hubei Province (No. Q2015010).

\section{References}

1 X. Shi, J. Inorg. Biochem., 1994, 56, 155.

2 Z. Meng, G. Qin, B. Zhang and J. Bai, Mutagenesis, 2004, 19, 465.

3 (a) R. F. McFeeters, J. Food Prot., 1998, 61, 885; (b) T. Fazio and C. R. Warner, Food Addit. Contam., 1990, 7, 433; (c) S. L. Taylor, N. A. Higley and R. K. Bush, in Advances in Food Research, ed. E. M. M. C. O. Chichester and B. S. Schweigert, Academic Press, 1986, vol. 30, pp. 1-76.

4 S. Iwasawa, Y. Kikuchi, Y. Nishiwaki, M. Nakano, T. Michikawa, T. Tsuboi, S. Tanaka, T. Uemura, A. Ishigami, H. Nakashima, T. Takebayashi, M. Adachi, A. Morikawa, K. Maruyama, S. Kudo, I. Uchiyama and K. Omae, J. Occup. Health, 2009, 51, 38.

5 G. Li and N. Sang, Ecotoxicol. Environ. Saf., 2009, 72, 236.

6 N. Sang, Y. Yun, H. Li, L. Hou, M. Han and G. Li, Toxicol. Sci., 2010, 114, 226-236.

7 (a) M. H. Stipanuk and I. Ueki, J. Inherited Metab. Dis., 2011, 34, 17; (b) N. D. Mathew, D. I. Schlipalius and P. R. Ebert, J. Toxicol., 2011, 2011, 14; (c) J. Li, R. Li and Z. Meng, Eur. J. Pharmacol., 2010, 645, 143.

8 (a) Z. Xu and L. Xu, Chem. Commun., 2016, 52, 1094; (b) S. Christoph and M. B. Sergey, Methods Appl. Fluoresc., 2015, 3, 042005.

9 (a) M. H. Lee, J. S. Kim and J. L. Sessler, Chem. Soc. Rev., 2015, 44, 4185; (b) G. R. Hamilton, S. K. Sahoo, S. Kamila, N. Singh,
N. Kaur, B. W. Hyland and J. F. Callan, Chem. Soc. Rev., 2015, 44, 4415.

10 (a) X. Liu, Q. Yang, W. Chen, L. Mo, S. Chen, J. Kang and X. Song, Org. Biomol. Chem., 2015, 13, 8663; (b) C. Yu, M. Luo, F. Zeng and S. Wu, Anal. Methods, 2012, 4, 2638.

11 (a) Y. Zhang, L. Guan, H. Yu, Y. Yan, L. Du, Y. Liu, M. Sun, D. Huang and S. Wang, Anal. Chem., 2016, 88, 4426; (b) J. Yang, K. Li, J.-T. Hou, L. L. Li, C. Y. Lu, Y. M. Xie, X. Wang and X. Q. Yu, ACS Sens., 2016, 1, 166; (c) J. Xu, J. Pan, X. Jiang, C. Qin, L. Zeng, H. Zhang and J. F. Zhang, Biosens. Bioelectron., 2016, 77, 725; (d) W. L. Wu, Z. Y. Wang, X. Dai, J. Y. Miao and B. X. Zhao, Sci. Rep., 2016, 6, 25315; (e) G. Wang, H. Chen, X. Chen and Y. Xie, $R S C A d v ., 2016,6$, 18662; (f) H. Li, Q. Yao, J. Fan, C. Hu, F. Xu, J. Du, J. Wang and X. Peng, Ind. Eng. Chem. Res., 2016, 55, 1477; (g) Q. Zhang, Y. Zhang, S. Ding, H. Zhang and G. Feng, Sens. Actuators, B, 2015, 211, 377; $(h)$ H. Zhang, Z. Huang and G. Feng, Anal. Chim. Acta, 2016, 920, 72 .

12 (a) H. Zhang, S. Xue and G. Feng, Sens. Actuators, B, 2016, 231, 752; (b) C. Liu, H. Wu, W. Yang and X. Zhang, Anal. Sci., 2014, 30, 589; (c) P. Hou, S. Chen, K. Voitchovsky and X. Song, Luminescence, 2014, 29, 749; (d) X. Ma, C. Liu, Q. Shan, G. Wei, D. Wei and Y. Du, Sens. Actuators, B, 2013, 188, 1196; (e) S. Chen, P. Hou, J. Wang and X. Song, $R S C$ Adv., 2012, 2, 10869; $(f)$ X. Gu, C. Liu, Y.-C. Zhu and Y. Z. Zhu, J. Agric. Food Chem., 2011, 59, 11935; (g) M. G. Choi, J. Hwang, S. Eor and S. K. Chang, Org. Lett., 2010, 12, 5624.

13 (a) C. Wang, S. Feng, L. Wu, S. Yan, C. Zhong, P. Guo, R. Huang, X. Weng and X. Zhou, Sens. Actuators, B, 2014, 190, 792; (b) Y. Sun, C. Zhong, R. Gong, H. Mu and E. Fu, J. Org. Chem., 2009, 74, 7943.

14 R. Y. Tsien and M. Poenie, Trends Biochem. Sci., 1986, 11, 450.

15 (a) L. Yuan, W. Lin, K. Zheng, L. He and W. Huang, Chem. Soc. Rev., 2013, 42, 622; (b) J. Fan, M. Hu, P. Zhan and X. Peng, Chem. Soc. Rev., 2013, 42, 29; (c) G. Chen, F. Song, X. Xiong and X. Peng, Ind. Eng. Chem. Res., 2013, 52, 1122.

16 Y. Lv, P. Liu, H. Ding, Y. Wu, Y. Yan, H. Liu, X. Wang, F. Huang, Y. Zhao and Z. Tian, ACS Appl. Mater. Interfaces, 2015, 7, 20640-20648. 